\title{
A 68-Year-Old Phenotypically Male Patient with 21-Hydroxylase Deficiency and Concomitant Adrenocortical Neoplasm Producing Testosterone and Cortisol
}

\author{
Masayuki Hayashi, ${ }^{1}$ Yuko Kataoka, ${ }_{1}^{1}$ Yoshihisa Sugimura, ${ }^{2}$ Fumiko Kato, ${ }^{3,4}$ \\ Maki Fukami, ${ }^{3}$ Tsutomu Ogata,,${ }^{3,4}$ Keiko Homma, ${ }^{5}$ Tomonobu Hasegawa, ${ }^{6}$ \\ Yutaka Oiso, ${ }^{2}$ Hironobu Sasano ${ }^{7}$ and Hiroshi Tanaka ${ }^{1}$ \\ ${ }^{1}$ Department of Endocrinology and Metabolism, Chukyo Hospital, Nagoya, Aichi, Japan \\ ${ }^{2}$ Department of Endocrinology and Diabetes, Field of Internal Medicine, Nagoya University Graduate School of \\ Medicine, Nagoya, Aichi, Japan \\ ${ }^{3}$ Department of Molecular Endocrinology, National Research Institute for Child Health and Development, Tokyo, \\ Japan \\ ${ }^{4}$ Department of Pediatrics, Hamamatsu University School of Medicine, Hamamatsu, Shizuoka, Japan \\ ${ }^{5}$ Central Clinical Laboratories, Keio University Hospital, Tokyo, Japan \\ ${ }^{6}$ Department of Pediatrics, Keio University School of Medicine, Tokyo, Japan \\ ${ }^{7}$ Department of Pathology, Tohoku University Graduate School of Medicine, Sendai, Miyagi, Japan
}

The steroidogenic enzyme 21-hydroxylase is necessary for the synthesis of both glucocorticoids and mineralocorticoids. 21-hydroxylase is a cytochrome P-450 enzyme and is encoded by the gene CYP21A2. Here we report a 68-year-old phenotypically 'male' but genetically female patient with 21-hydroxylase deficiency (21OHD) and the concomitant virilizing adrenocortical carcinoma. This patient grew up as a male and has not encountered any episodes of adrenal insufficiency without glucocorticoid replacement in his lifetime. A chromosome test at admission, however, identified the 46, XX karyotype, and serum 17-hydroxyprogesterone and urine pregnanetriolone and 11 $\beta$-hydroxyandrostendione were all elevated, consistent with 21OHD. Moreover, serum testosterone was $1.90 \mathrm{ng} / \mathrm{ml}$, much higher than the female standard levels, and serum cortisol was $5.7 \mu \mathrm{g} / \mathrm{ml}$, slightly lower than standard levels. Genetic analysis identified the patient as a heterozygote of the two pathogenic mutations in the CYP21A2 gene: IVS2$13 C(A)>G$ and R356W. Magnetic resonance imaging (MRI) revealed the presence of left adrenal tumor measuring $6 \mathrm{~cm}$, which was subsequently diagnosed as adrenocortical carcinoma based on the criteria of Weiss. Immunohistochemical analysis of the tumor specimens revealed the expression of various enzymes involved in testosterone production, including 3 $\beta$-hydroxysteroid dehydrogenase, $17 \alpha$-hydroxylase/17,20lyase, and $17 \beta$-hydroxysteroid dehydrogenase. Importantly, the expression of immunoreactive 21-hydroxylase was detected in these tumor cells. The levels of adrenal tumor-derived steroid metabolites were all markedly decreased following the surgery. This is the first report on a virilized 21OHD patient associated with the adrenocortical tumor that produces testosterone. Moreover, the concomitant adrenocortical tumor may ameliorate adrenocortical insufficiency by producing cortisol.

Keywords: adrenocortical carcinoma; cortisol; 21-hydroxylase deficiency; prominent masculinization; testosterone Tohoku J. Exp. Med., 2013 October, 231 (2), 75-84. C 2013 Tohoku University Medical Press

\section{Introduction}

The steroidogenic enzyme 21-hydroxylase is necessary for the synthesis of both glucocorticoids and mineralocorticoids, and its deficiency is responsible for over $90 \%$ of the cases with congenital adrenal hyperplasia $(\mathrm{CAH})$. The enzyme 21-hydroxylase is a cytochrome P-450 enzyme, also known as P450c21. The genes encoding P450c21,
CYP21A2, and a pseudogene, CYP21P, are located on chromosome 6 p21.3, adjacent to genes $C 4 B$ and $C 4 A$, encoding two isoforms of the fourth component in the class III region of the HLA complex (Carroll et al. 1985; White et al. 1985). Mutations in the CYP21A2 gene usually result in various degrees of impaired cortisol and aldosterone synthesis and excess androgens (Merke and Bornstein 2005; Nimkarn et al. 2011). The clinical presentation of 21-hydroxylase defi-

Received June 11, 2013; revised and accepted September 17, 2013. Published online September 28, 2013; doi: 10.1620/tjem.231.75.

Correspondence: Masayuki Hayashi, Department of Endocrinology and Metabolism, Chukyo Hospital, 1-1-10, Sanjo, Minami-ku, Nagoya, Aichi 457-8510, Japan.

e-mail: masayuki_hayashi@chukyo-hosp.jp 
ciency (21OHD) has been further classified as the classical form, including the salt wasting (SW) and simple virilizing (SV) subclasses and the non-classical (NC) or late-onset form, based upon the different degrees of deficiency in enzymatic activity (Zhang et al. 2009). In Japan, a nationwide neonatal mass-screening program for $\mathrm{CAH}$ measuring serum $17 \alpha$-hydroxyprogesterone (17OHP) levels has been available since 1989, which has also made those with classical 21OHD diagnosed at an older age extremely unlikely (Shinagawa et al. 2007). In addition, the patients with 21OHD are associated with marked proliferation of the zonae fasciculate and reticularis especially in untreated conditions with excessive adrenocorticotropic hormone (ACTH) levels, but rarely developed adrenocortical carcinoma, except for a few cases of classical 21OHD (Hamwi et al. 1957; Bauman and Bauman 1982; Jaursch-Hancke et al. 1988). Virilized 46, XX classical 21OHD patients are rarely raised as male (Lee and Houk 2010).

In this report, we described a 68-year-old phenotypically male but genetically female classical $210 H D$ patient associated with testosterone production and adrenocortical carcinoma. The concomitant adrenocortical carcinoma may ameliorate adrenocortical insufficiency by producing cortisol.

\section{Patient and Methods}

\section{Patient}

A 68-year-old Japanese phenotypically male (Fig. 1A and B) presented with left adrenal incidentaloma, which was identified when he underwent abdominal computed tomography (CT) as the health check-up (Fig. 1C). The adrenal tumor measured $34.9 \times 54.7 \times 55.0$ $\mathrm{mm}$. The patient was raised as a man since birth but underwent testis plasty due to testicular dysgenesis when the patient was 11 years old but he has never been diagnosed as 21OHD at all until the current admission. Family history was not contributory. Physical examination on admission revealed that height was $138 \mathrm{~cm}$, weight $51 \mathrm{~kg}$, and body mass index 26. The pubic hair was kinky and thin but the patient was phenotypically male based on his muscular extremities and the resemblance of the external genitalia to a penis rather than a clitoris (Fig. 1A and B).

Laboratory data on first admission were summarized in Table 1. Adrenocortical hormonal abnormalities were clinically not apparent. Abdominal magnetic resonance imaging (MRI) demonstrated that the right adrenal gland was morphologically normal (Fig. 1D) with artificial materials in the scrotum (Fig. 1G). In addition, the internal genitalia simulating uterus or ovary was located in the space left dorsal to the urinary bladder, suggesting either anomalies of Mullerian duct or testis formation, respectively (Fig. 1E and F). Urine cortisol excretion was slightly below normal. The patient did not have any clinical symptoms suggestive of adrenocortical insufficiency such as general malaise, but primary adrenocortical insufficiency was hormonally suspected because of an increased ACTH level up to $110 \mathrm{pg} / \mathrm{ml}$ and a decreased cortisol level of $5.7 \mu \mathrm{g} / \mathrm{ml}$ (Table 1). The diagnosis was confirmed by subsequent ACTH test (see Fig. 2H). Oral administration of hydrocortisone (10 $\mathrm{mg}$ per day) was subsequently initiated to treat this adrenocortical insufficiency.

In addition to the findings above, the serum testosterone levels
$(1.90 \mathrm{ng} / \mathrm{ml})$ of this phenotypically male but genetically female patient was found to be lower than the male (2.07-7.61) but higher than the female standard levels (0.13-0.69) (Table 1), as well as basal serum levels of luteinizing hormone $(\mathrm{LH} ;<0.01 \mathrm{mIU} / \mathrm{ml})$ and follicle-stimulating hormone (FSH; $1.48 \mathrm{mIU} / \mathrm{ml}$ ). These data were consistent with the presence of hypogonadotropic hypogonadism, consistent with the results of the LH-releasing hormone (LHRH)stimulation test (Fig. 2A and B). In addition, ACTH response to corticotropin releasing hormone $(\mathrm{CRH})$ was exaggerated (Fig. 2F). Other pituitary functions were within normal limits (Fig. 2C-E).

Due to the possibility of malignancy based on the tumor size (diameter $6 \mathrm{~cm}$ ), the patient underwent a laparoscopic left adrenalectomy in August 2010. After the operation, hydrocortisone was tapered. When the dose was reduced to $10 \mathrm{mg}$ /day, which was the same dose used before the operation, the patient clinically experienced bouts of marked general fatigue consistent with an increased serum ACTH level and decreased serum cortisol and aldosterone levels with $10 \mathrm{mg}$ hydrocortisone administration. Progression of adrenal insufficiency was suspected, and hydrocortisone $(20 \mathrm{mg} /$ day $)$ was orally re-administered. Re-evaluation of both pituitary and adrenal functions in March 2011 revealed the normalization of serum LH (20.71 mIU/ml) and FSH (57.49 mIU/ml) levels, while LHRHstimulated LH and FSH responses had recovered but were not completely normalized (Fig. 2A and B). In contrast, serum testosterone level had markedly declined to undetectable ones $(0.05>\mathrm{ng} / \mathrm{ml})$ and serum estradiol level also decreased from $28 \mathrm{pg} / \mathrm{ml}$ to undetectable levels $(10>\mathrm{pg} / \mathrm{ml})$ after the operation. We recommended testosterone supplementation to this phenotypically male but genetically female patient to maintain masculinization but the patient eventually declined the hormone therapy. The external penis-like genitalia became more atrophic at this visit compared to before the operation. $\mathrm{CRH}$-stimulated serum ACTH and cortisol responses were excessive and mild, respectively (Fig. 2F and G). Post-operative basal and ACTH-stimulated serum cortisol levels were lower than pre-operative levels (Fig. 2H). Results of other pituitary function tests were the same as before the surgery (Fig. 2C-E). Urine free-cortisol and aldosterone were decreased to undetectable levels (Table 2). These findings all indicated that the primary adrenal insufficiency had progressed following the resection of the adrenal tumor in this patient despite the hydrocortisone replacement therapy.

Blood samples were collected for genetic analysis after appropriate written informed consent had been obtained in accordance with the Declaration of Helsinki. After the diagnosis, the patient received psychological counseling by his doctor.

\section{Immunohistochemistry}

Immunohistochemical analysis of steroidogenic enzymes was performed on $10 \%$ formalin-fixed paraffin-embedded specimens employing the biotin-strept avidin (B-SA) amplified method using the StrAvi-Gen B-SA immunostaining system (Biogenex, CA, USA). The antibodies used were against 21-hydroxylase (CYP21) (White et al. 1984), 17 $\alpha$-hydroxylase/17,20-lyase (CYP17) (Sasano et al. 1992), dehydroepiandrosterone sulfotransferase (DHEAST) (Santa Cruz, CA, USA), $3 \beta$-hydroxysteroid dehydrogenase ( $3 \beta \mathrm{HSD}$ ) (Lorence et al. 1990), or $17 \beta$-hydroxysteroid dehydrogenase type 5 (17 $\beta$ HSD5) (Sigma-Aldrich, MO, USA) (Nakamura et al. 2009). For positive control of immunostaining, we used normal human adrenal (CYP21, CYP17, DHEAST and $3 \beta \mathrm{HSD}$ ) and testis (17 $\beta$ HSD5). For negative control, we used normal rabbit IgG (CYP21, CYP17, DHEAST and 

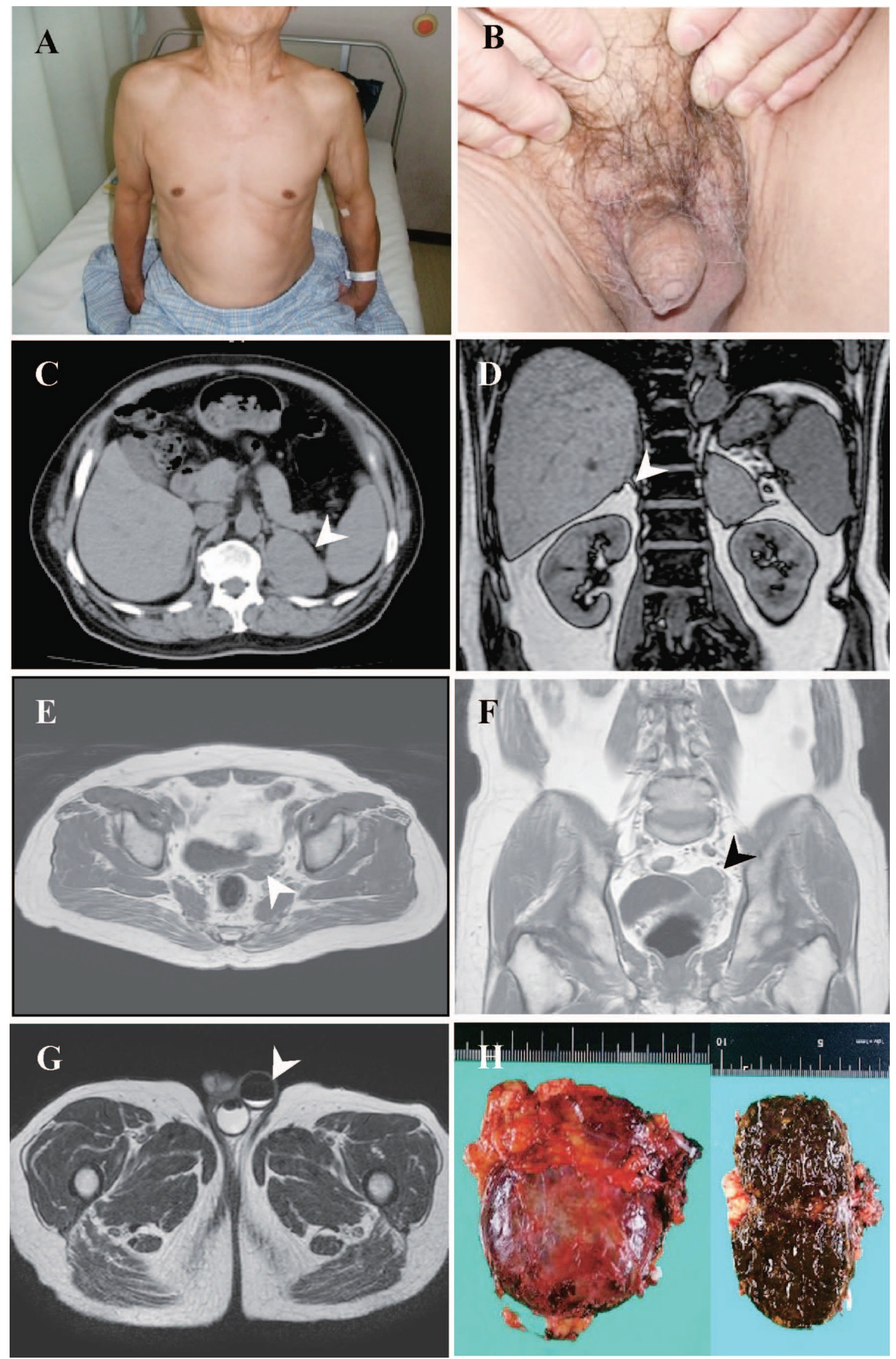

Fig. 1. Photographs of the patient and CT and MRI imaging of the abdomen.

The upper body is well muscled (A) with small male-like genitalia (B). CT scan shows massively enlarged left adrenal gland (C) and sagittal section of abdominal MRI shows a normal right adrenal gland (D). A uterus like structure was detected behind the bladder (E and F). Plastic materials were inserted into the scrotum when testis plasty was performed in his childhood $(\mathrm{G})$. Macroscopic view of cut surface and section of the adrenal tumor is shown $(\mathrm{H})$. 
[Biochemistry]

Table 1. Laboratory data on admission.

\begin{tabular}{|lrlr|}
\hline Blood urea nitrogen & $16 \mathrm{mg} / \mathrm{dl}$ & Triglyceride & $\underline{355} \mathrm{mg} / \mathrm{dl}$ \\
Creatinine & $0.84 \mathrm{mg} / \mathrm{dl}$ & High-density lipoprotein & $\underline{23} \mathrm{mg} / \mathrm{dl}$ \\
Uric acid & $7.0 \mathrm{mg} / \mathrm{dl}$ & Low-density lipoprotein & $123 \mathrm{mg} / \mathrm{dl}$ \\
Sodium & $139 \mathrm{mEq} / \mathrm{dl}$ & Blood sugar & $5.7 \%$ \\
Potassium & $3.9 \mathrm{mEq} / \mathrm{l}$ & HbAlc & \\
Chloride & $106 \mathrm{mEq} / \mathrm{l}$ & & \\
\hline
\end{tabular}

[Endocrinology]

\begin{tabular}{|c|c|c|c|}
\hline Thyroid stimulating hormone & $0.950 \mu \mathrm{IU} / \mathrm{ml}$ & Plasma renin activity & $5.2 \mathrm{ng} / \mathrm{ml} / \mathrm{hr}$ \\
\hline Free triiodothyronine & $3.3 \mathrm{pg} / \mathrm{ml}$ & Aldosterone & $116 \mathrm{pg} / \mathrm{ml}$ \\
\hline Free thyroxine & $1.2 \mathrm{ng} / \mathrm{dl}$ & Adrenaline & $0.02 \mathrm{ng} / \mathrm{ml}$ \\
\hline Growth hormone & $0.821 \mathrm{ng} / \mathrm{ml}$ & Noradrenaline & $0.27 \mathrm{ng} / \mathrm{ml}$ \\
\hline Insulin-like growth factor 1 & $320 \mathrm{ng} / \mathrm{ml}$ & Dopamine & $<0.03 \mathrm{ng} / \mathrm{ml}$ \\
\hline Adrenocorticotropic hormone (ACTH) & $\underline{110} \mathrm{pg} / \mathrm{ml}$ & Luteinizing hormone & $\leq 0.01 \mathrm{mIU} / \mathrm{ml}$ \\
\hline Cortisol & $\underline{5.7} \mu \mathrm{g} / \mathrm{ml}$ & Follicle-stimulating hormone & $\underline{1.48} \mathrm{mIU} / \mathrm{ml}$ \\
\hline Dehydroepiandrosterone sulfate & $126 \mu \mathrm{g} / \mathrm{dl}$ & Testosterone & $\underline{1.90} \mathrm{ng} / \mathrm{ml}$ \\
\hline Estradiol & $28 \mathrm{pg} / \mathrm{ml}$ & & \\
\hline Pregnenolone & $1.37 \mathrm{ng} / \mathrm{ml}$ & $(0.2-1.5)$ & \\
\hline Progesterone & $20.7 \mathrm{ng} / \mathrm{ml}$ & $(<0.88)$ & \\
\hline 11-deoxycorticosterone & $0.72 \mathrm{ng} / \mathrm{ml}$ & $(0.03-0.33)$ & \\
\hline Corticosterone & $11.00 \mathrm{ng} / \mathrm{ml}$ & $(0.21-8.48)$ & \\
\hline 18-hydroxycorticosterone & $0.23 \mathrm{ng} / \mathrm{ml}$ & $(0.01-0.07)$ & \\
\hline Aldosterone & $116 \mathrm{pg} / \mathrm{ml}$ & $(30-160)$ & \\
\hline $17 \alpha$-hydroxypregnenolone & $15.20 \mathrm{ng} / \mathrm{ml}$ & $(0.1-4.0)$ & \\
\hline $17 \alpha$-hydroxyprogesterone & $130 \mathrm{ng} / \mathrm{ml}$ & $(0.2-4.5)$ & \\
\hline 11-deoxycortisol & $0.72 \mathrm{ng} / \mathrm{ml}$ & $(0.11-0.60)$ & \\
\hline Androstenedione & $5.3 \mathrm{ng} / \mathrm{ml}$ & $(0.3-2.0)$ & \\
\hline $5 \alpha$-dihydrotestosterone & $0.18 \mathrm{ng} / \mathrm{ml}$ & $(0.05-0.3)$ & \\
\hline
\end{tabular}

[Overnight $1 \mathrm{mg}$ dexamethasone suppression test]

$\begin{array}{llcl}\mathrm{ACTH} & 1.1 \mathrm{pg} / \mathrm{ml} & \text { Cortisol } & 0.8 \mu \mathrm{g} / \mathrm{ml}\end{array}$

The underlined numbers are deviated from normal range. Dyslipidemia was diagnosed because of the elevated serum triglyceride and decreased high-density lipoprotein levels. Serum elevated ACTH and decreased cortisol levels suggested primary adrenocortical insufficiency. Furthermore, decreased luteinizing hormone and follicle-stimulating hormone levels were consistent with the presence of hypogonadotropic hypogonadism, while serum testosterone levels were much higher than the female standard levels.

$3 \beta \mathrm{HSD})$ or $0.01 \mathrm{M}$ PBS (17 $\beta$ HSD5) instead of the primary antibodies and no specific immunoreactivity was detected (data not shown). To further determine the characteristics of the adrenal tumor, monoclonal mouse Ki-67 and CD31 antibodies (DAKO, Denmark), and monoclonal mouse CD34 antibody (Nichirei, Tokyo, Japan) were used for immunochemistry. Immunostaining procedures and properties of primary antibodies used in this study have been described in detail previously (Sasano et al. 1992).

\section{Direct sequence analysis}

Genomic DNA from blood samples was subjected to direct sequencing of the coding exons and flanking splice sites of CYP21A2, using previously reported polymerase chain reaction (PCR) primers (Koyama et al. 2002). To confirm a heterozygous mutation, the corresponding PCR products were subcloned with a TOPO TA Cloning Kit (Invitrogen, Carlsbad, CA, USA), and the two alleles were sequenced separately.

Urine steroid profile analysis

Urine samples were randomly collected for the study and kept at $-20^{\circ} \mathrm{C}$ until analysis. We studied this patient and control women ( $n$ $=19,50-59$ years of age) for urinary steroid profile by gas chromatography-mass spectrometry/selected ion monitoring (GC-MS-SIM), as reported (Homma et al. 2003; Koyama et al. 2012). In brief, 0.05to $0.2-\mathrm{mL}$ urine samples were subjected to enzymatic hydrolysis, organic solvent extraction and methyloximetrimethylsilyl derivatization, and the derivative was subjected to GC-MS-SIM analysis. GC-MS-SIM analysis was performed on an HP5890II GC with an HP-Ultra1 fused silica column $(25 \mathrm{~m} \times 0.2 \mathrm{~nm} \times 0.33 \mu \mathrm{m})$ coupled to an HP5973MS (Agilent Technologies, Santa Clara, CA, USA). 

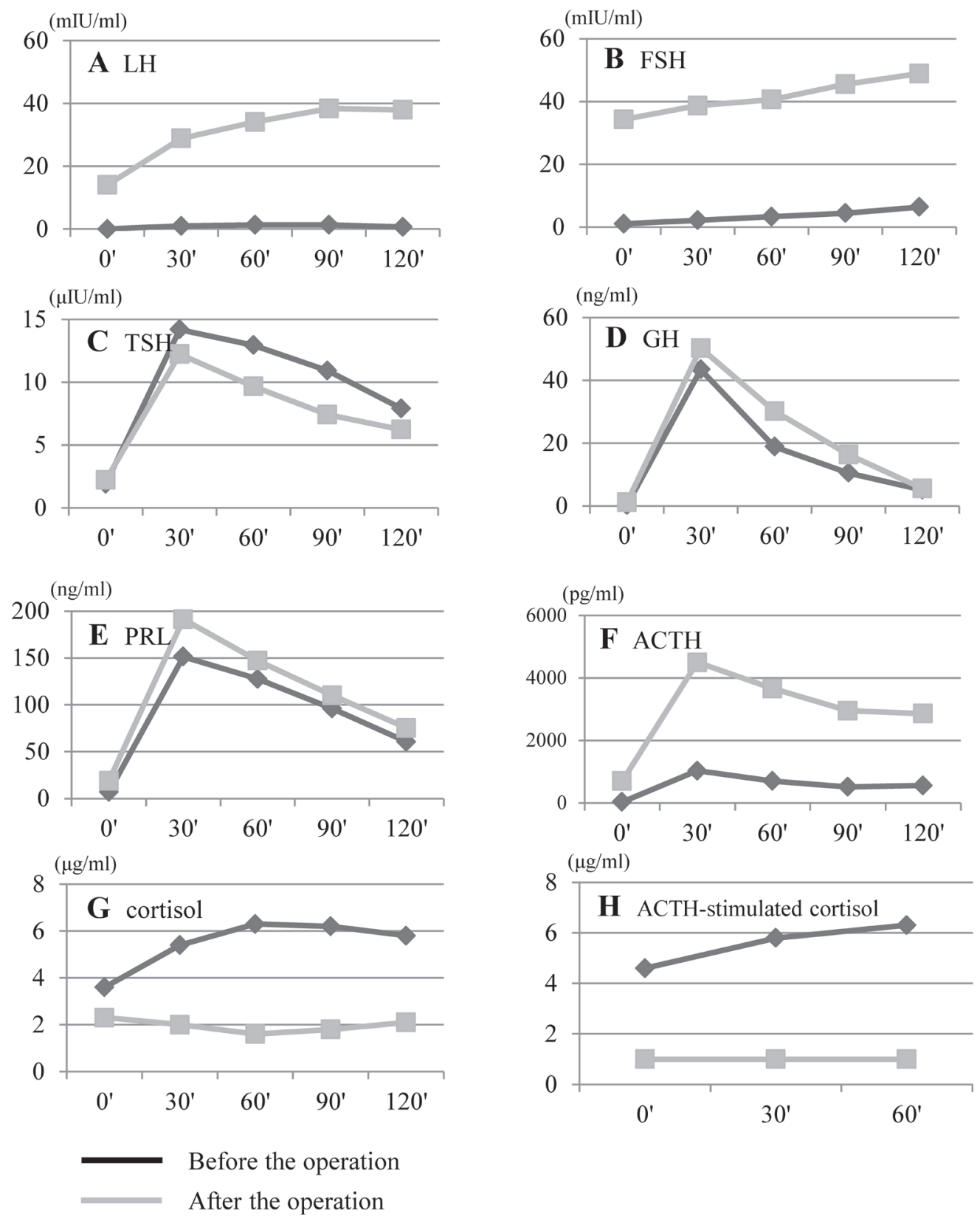

Fig. 2. Anterior pituitary and adrenal function tests performed before and after the operation.

Anterior pituitary and adrenal function tests were performed before (black line) and after (gray line) the resection of the left adrenal. Basal luteinizing hormone (LH) (A) and follicle-stimulating hormone (FSH) (B) levels were elevated after the operation, and luteinizing hormone-releasing hormone (LHRH)-stimulated LH and FSH levels were no response before the operation, but partially recovered after it. Thyrotropin-releasing hormone (TRH)-stimulated serum thyroid stimulating hormone (TSH) levels (C), growth hormone releasing peptide-2 (GHRP-2) stimulated serum growth hormone (GH) levels (D), and TRH-stimulated serum prolactin (PRL) levels (E) showed almost identical reactions before and after the operation. However, corticotropin-releasing hormone (CRH)-stimulated serum adrenocorticotropic hormone $(\mathrm{ACTH})$ levels $(\mathrm{F})$ were higher, and $\mathrm{CRH}$-stimulated serum cortisol levels $(\mathrm{G})$ were lower after the operation than those before the operation. Furthermore, ACTH-stimulated serum cortisol levels (H) showed no response after the operation. These data indicate that primary adrenal insufficiency progressed after the tumor resection.

\section{Results}

\section{Genetic analysis}

A chromosome test identified the 46, XX karyotype by both G-banding and fluorescent in-situ hybridization
(FISH), and the expression of the sex determination gene on chromosome Y (SRY) was negative on chromosome X, indicating that the patient was female and not the typical XX male. Genetic analysis by PCR-direct sequencing disclosed two mutations in the CYP21A2 gene: IVS2- 
IVS2-13C(A) $>\mathrm{G}$

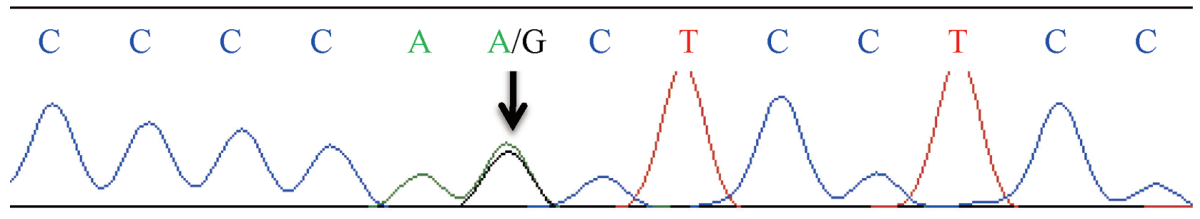

R356W

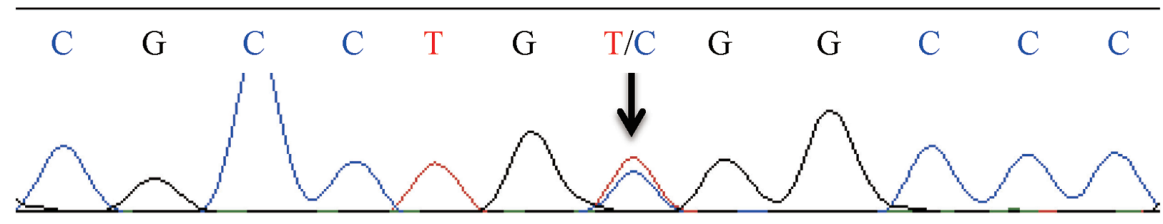

Fig. 3. Sequence analysis of $C Y P 21 A 2$ gene.

Single nucleotide conversions in intron 2 (IVS2-13C(A) $>$ G) and exon 8 (R356W) are demonstrated.

Table 2. Steroid profiles in the urine samples before and after the operation.

\begin{tabular}{llcc}
\hline \multicolumn{1}{c}{ Urine Samples } & \multicolumn{1}{c}{ Reference data } & $\begin{array}{c}\text { Pre-operative } \\
\text { July, 2010 }\end{array}$ & $\begin{array}{c}\text { Post-operative } \\
\text { Mar, 2011 }\end{array}$ \\
\hline Pregnanetriolone & $0.010-0.048 \mathrm{mg} / \mathrm{g}$ creatinine & 17.134 & 0.042 \\
$11 \beta$-hydroxyandrosterone & $0.388-0.884 \mathrm{mg} / \mathrm{g}$ creatinine & 13.444 & 0.161 \\
Free cortisol & $11.2-80.3 \mu \mathrm{g} / \mathrm{day}$ & 7.0 & u.d. \\
Aldosterone & $10>\mu \mathrm{g} /$ day & 10.3 & 2.3 \\
Adrenaline & $1-23 \mu \mathrm{g} / \mathrm{day}$ & 5.0 & 8.5 \\
Noradrenaline & $29-120 \mu \mathrm{g} / \mathrm{day}$ & 114 & 249 \\
Dopamine & $100-1,000 \mu \mathrm{g} /$ day & 600 & 640 \\
Metanephrine & $0.05-0.20 \mathrm{mg} /$ day & 0.11 & 0.10 \\
Normetanephrine & $0.10-0.28 \mathrm{mg} /$ day & 0.27 & 0.61 \\
\hline
\end{tabular}

u.d., undetectable.

$13 \mathrm{C}(\mathrm{A})>\mathrm{G}$ in intron 2 and $\mathrm{R} 356 \mathrm{~W}$ in exon 8 . Of these, IVS2-13C(A) $>\mathrm{G}$ is a substitution of a nucleotide at the 13th position from the splice donor site of exon 3 ( $\mathrm{C}$ or $\mathrm{A}$ in unaffected individuals) to $\mathrm{G}$. This mutation has been shown to cause aberrant splicing and subsequent frame-shift, leading to a premature stop codon (Higashi et al. 1988). R356W is a missense mutation that substitutes $\operatorname{Trp}$ for Arg356 in exon 8 (Fig. 3) (Koyama et al. 2002).

\section{Serum and Urine steroid profile}

A serum steroid profile performed to rule out $\mathrm{CAH}$, as shown in Table 1, showed an extraordinarily high level of serum 17OHP indicating 210HD. A urine steroid profile showed that pregnanetriolone (a metabolite of 21-deoxycortisol) and 11 $\beta$-hydroxyandrosterone (a metabolite of $11 \beta$-hydroxyandrostenedione), both sensitive indicators of 21OHD (Homma et al. 2004; Koyama et al. 2012), were higher than reference levels (Table 2), confirming the diagnosis of 210HD. At birth, the patient did not have a SW crisis, and was sufficiently masculinized to be male pheno- type despite the 46, XX karyotype. Based on all these findings, we diagnosed this patient with $21 \mathrm{OHD}$, classical SV type.

Macroscopic and histopathological findings of the adrenal tumor

The tumor weighed $60 \mathrm{~g}$ and its outer surface appeared yellow to brown but the cut surface appeared black or dark brown (Fig. 1H), presumably derived from accumulated lipofuscin in the cytosol of tumor cells. Normal adrenal was attached to the tumor (data not shown). We evaluated the cell proliferation by determining a Ki-67 labeling index of 4.5\% (Iino et al. 1997; Nakazumi et al. 1998) (Fig. 4A). Histopathological examination also demonstrated the presence of venous invasion demonstrated by CD31 immunostaining (Fig. 4B), and sinusoidal invasion by CD34 immunostaining (Fig. 4C). The tumor was subsequently diagnosed as adrenocortical carcinoma according to the Weiss's criteria (four <sinusoidal invasion, venous invasion, cytoplasm and capsular invasion $>$ of nine criteria were 

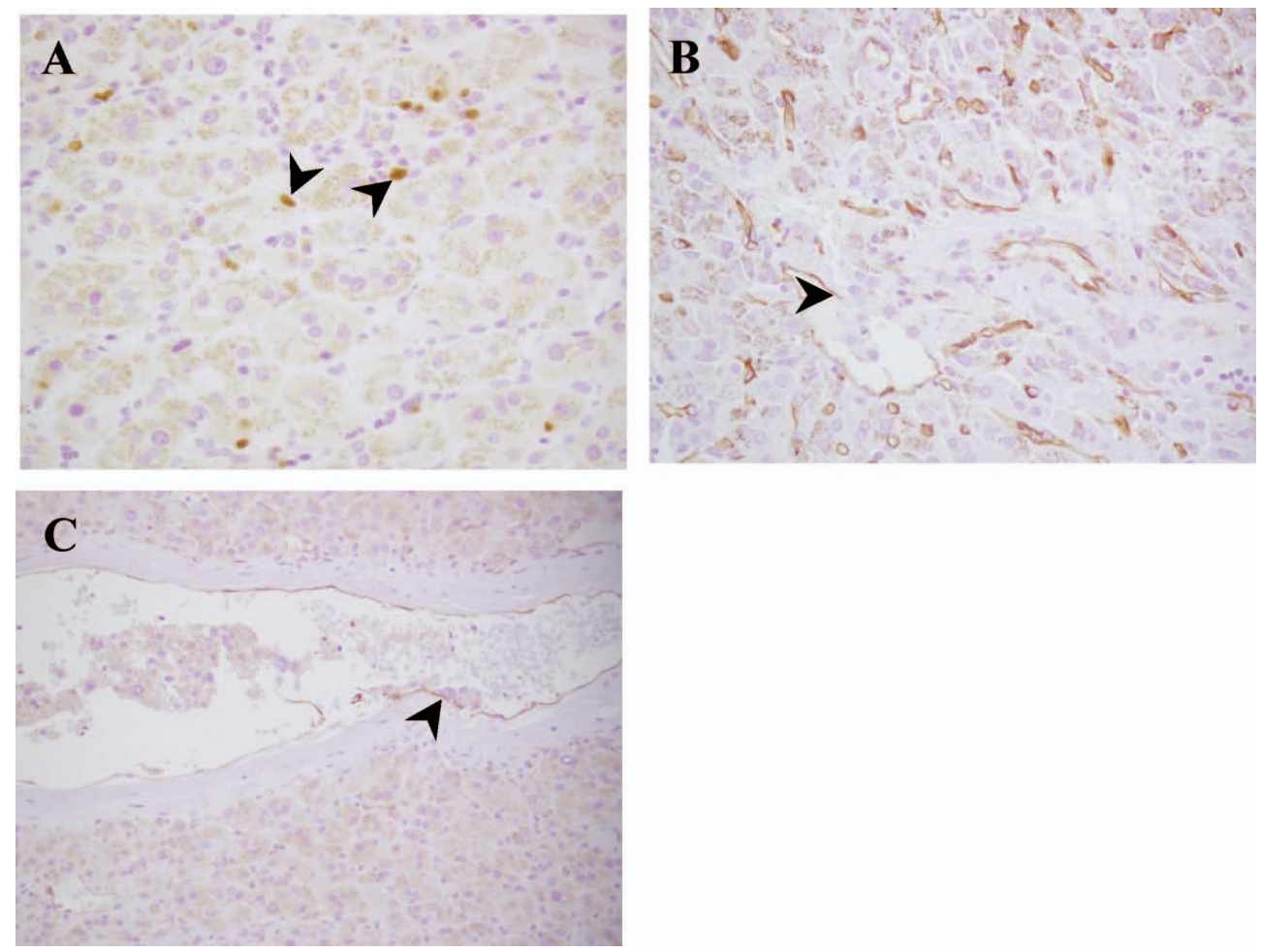

Fig. 4. Histopathologic findings of the resected specimen support malignancy.

The tumor cells contain lipofuscin in the cytosol, and representative Ki-67 positive cells are shown (arrowheads) (A). Representative photos of venous invasion supported by CD31 immunostaining (arrowheads) (B), and sinusoidal invasion by CD34 immunostaining (arrowheads) (C) suggest malignancy. Original magnification: $\times 200(A, B), \times 100(C)$.

met) of adrenocortical malignancy (Weiss 1984).

Immunohistochemistry of steroidogenic enzymes revealed weak but discernible immunoreactivity of CYP21 in the tumor (Fig. 5A), and immunoreactive $3 \beta \mathrm{HSD}$, CYP17, and DHEAST were all clearly detected (Fig. 5B-D). No positive cells were detected with control IgG (data not shown). We also demonstrated the presence of $17 \beta$ HSD5, a testosterone biosynthesis enzyme (Fig. 5E) in the tumor tissue, which accounted for the increased testosterone levels in this patient before the surgery.

\section{Discussion}

In this study, we demonstrated the presence of 21OHD, classic SV type and testosterone-producing adrenocortical carcinoma in the 68-year-old phenotypically male but genetically female patient with treatment naïve. This rather complicated patient is considered unique and informative because of the following three clinical and hormonal aspects: (1) the adrenocortical tumor turned out to be histopathologically malignant or carcinoma, (2) the tumor was considered to produce testosterone as a result of ectopic expression of $17 \beta \mathrm{HSD} 5$ as well as other corticosteroids, which contribute to the prevention of adrenocortical insufficiency despite no cortisol replacement and possibly further masculinization, and (3) unique patterns of 21OHD-related mutations, i.e., R356W and IVS2-13C(A) $>$ G, both of which have been reported more frequently in SW type than in SV type.

The prevalence of adrenal incidentaloma among 21OHD patients appear to be relatively high both in heterozygous and homozygous carriers of CAH (Jaresch et al. 1992). However, it is also true that relatively few cases of adrenocortical carcinoma have been reported in the literature in the patients with CAH (Hamwi et al. 1957; Bauman and Bauman 1982; Jaursch-Hancke et al. 1988). One similar patient has been reported, in which 21OHD, classical SV type, presented as massive adrenal masses in the seventh decade of life (Abo et al. 1999).

In our present patient, 21OHD was not diagnosed at birth, but firstly identified at the age of 68 years old. Among the patients with $\mathrm{CAH}$, complete virilization, such as the male external genitalia with absent testis, is wellknown but actually rare and almost all ( 95\%) 46, XX CAH infants develop a female phenotype (Lee and Houk 2010). However, the present patient was apparently male and the sexual identity of this particular patient had been male for the last 67 years. The prominent masculinization in this patient might have been accelerated by the existence of an adrenal tumor in addition to the phenotype of the classical SV type at birth. One possible explanation for this marked masculinization since birth was that the hormoneproducing tumor existed at an earlier stage of life but gradually transformed from benign to malignant at some point, although the process of adrenal tumorigenesis has remained 

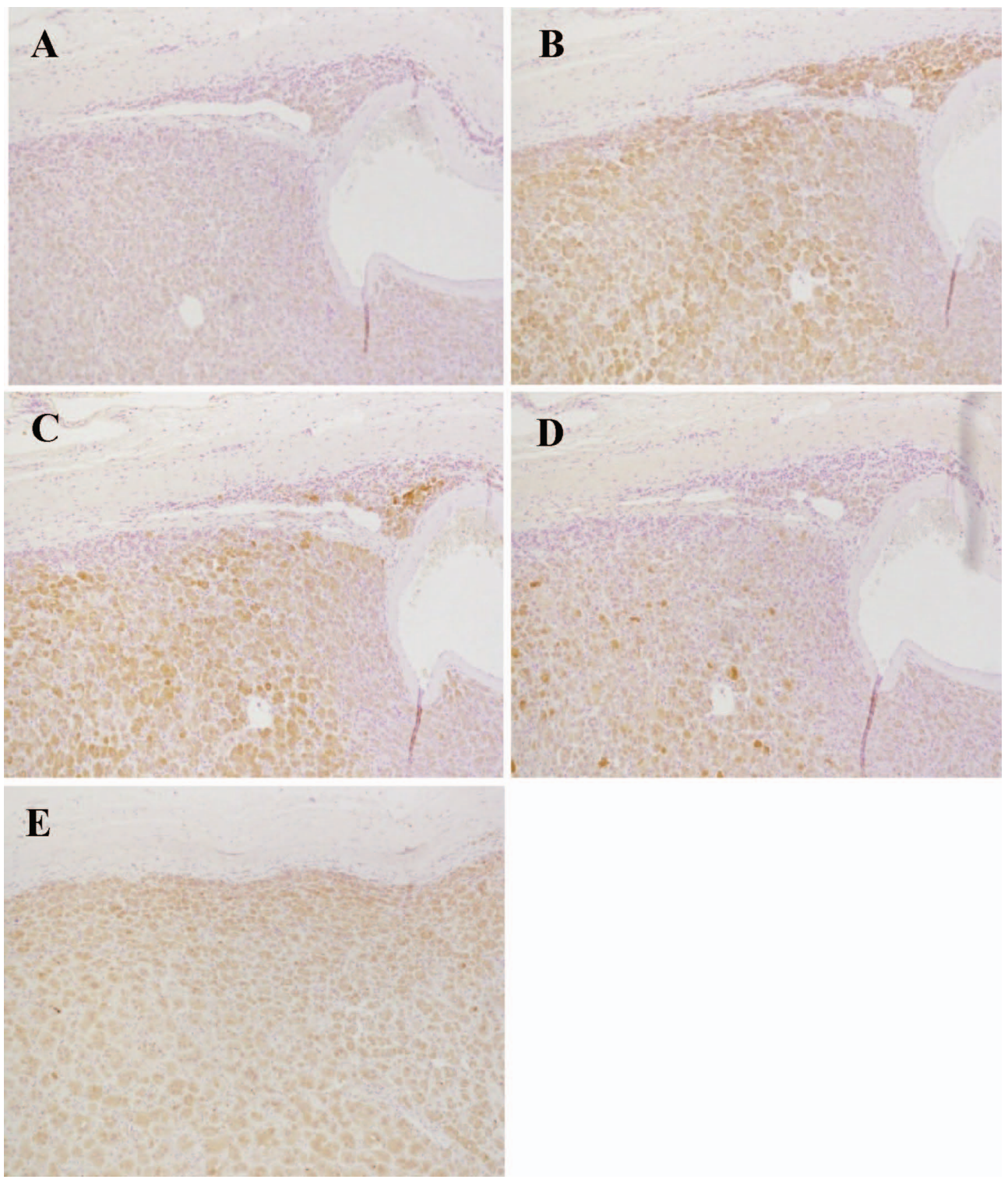

Fig. 5. Immunohistochemical staining of the tumor tissue for enzymes involved in the adrenal steroidogenesis. Positive immunoreactivity in adrenocortical tumor cells was identified as brown as a result of DAB colorimetric action. 21Hydroxylase (CYP21) (A) was weakly positive, while $3 \beta$-hydroxysteroid dehydrogenase (3 $\beta$ HSD) (B), $17 \alpha$-hydroxylase/17,20-lyase (CYP17) (C), and dehydroepiandrosterone sulfotransferase (DHEAST) (D), were expressed in the tumor. The immunoreactivity for $17 \beta$-hydroxysteroid dehydrogenase type 5 (17 $\beta$ HSD5) was detected in the tumor cells, consistent with overproduction of testosterone $(E)$. Original magnification: $\times 100$.

unclear. $17 \beta \mathrm{HSD} 5$, which regulates the conversion of androstenedione to testosterone, was expressed in human adrenal cortex, as judged by immunohistochemical analysis (Nakamura et al. 2009). However, 17 $\beta$ HSD5 mRNA level in the adrenals were much lower than that in the liver and prostate (Dufort et al. 1999). Therefore, the 17 $\beta$ HSD5 immunoreactivity in the tumor tissue of this patient is considered as an ectopic expression and to contribute to the overproduction of testosterone. Serum testosterone levels were higher than those in females, suggesting that increased testosterone levels might have contributed to the further masculinization before or after adolescence, although the period when the tumor developed remains unknown.
Post-operative urine cortisol levels decreased compared to the pre-operative levels, which suggested that cortisol was indeed produced by this concomitant carcinoma of this patient. In addition, the patient developed symptoms of adrenal insufficiency which progressed after adrenal tumor resection, although no symptoms prior to the operation despite no glucocorticoid replacement therapy. These findings all indicated that the adrenal tumor produced at least the steroid hormones required for maintaining water and mineral balance, essential for supporting life. The production of cortisol by the tumor is supported by the finding that the ectopic but discernible expression of CYP21 in the tumor. To the best of our knowledge, there is one report 
that suggests the production of cortisol by the adrenal tumor arising in the patient with 21OHD (Nagasaka et al. 1996). They reported that adrenal insufficiency developed after the surgical removal of the adrenal tumor and the pathological diagnosis was adrenocortical adenoma. Therefore, these tumors arising in the patients with $21 \mathrm{OHD}$ are considered to produce cortisol and contribute to the prevention of adrenocortical insufficiency despite no cortisol replacement through ectopic expression of CYP21. Preoperative levels of pregnanetriolone and $11 \beta$-hydroxyandrosterone were higher than post-operative levels and steroid hormones derived from the adrenal gland (except for orally administered hydrocortisone metabolites) were also decreased after the operation, indicating that the right adrenal gland did not produce enough steroid hormones, although it awaits further investigations for clarification. Of interest, the steroid production of left adrenal tumor was not necessarily autonomous based on the results of the $1 \mathrm{mg}$ dexamethasone suppression test (Table 1). The fact that suppressed LH and FSH secretion recovered following the operation might be due to the interference of excessive androstenedione and hypersecretion of progesterone with LH and FSH secretion (Bachelot et al. 2008) but it also awaits further investigations for clarification.

In our patient, we identified the two distinct mutations of R356W and IVS2-13C(A) $>\mathrm{G}$ in the CYP21A2 gene. R356W completely abolishes the enzyme activity of 21-hydroxylase, and IVS2-13C(A) $>\mathrm{G}$ results in the decrease or loss of the enzyme activity due to a frame-shift (Wedell et al. 1994; Koyama et al. 2002). Therefore, it is surprising that the present patient with classical SV type did not develop adrenal insufficiency. In fact, the numbers of $\mathrm{SW} / \mathrm{SV} / \mathrm{NC}$ forms harboring the present mutations were reported to be 3/1/0 (Koyama et al. 2002), 3/0/0 (Stikkelbroeck et al. 2003), 1/0/0 (Usui et al. 2004), 4/1/0 (Wilson et al. 1995), and 3/0/0 (Krone et al. 2000), respectively. In addition, to the best of our knowledge, this is the first report that shows the patient with classical SV type associated with adrenocortical carcinoma harboring the above double mutations.

In summary, we report a 68 -year-old phenotypically male but genetically female patient with $21 \mathrm{OHD}$, classical SV type, accompanied by unilateral adrenocortical carcinoma. Incidentally, the concomitant adrenocortical carcinoma produced steroid hormones, such as cortisol and testosterone, thereby contributing to the prevention of adrenocortical insufficiency and contributing to masculinization.

\section{Funding}

This study did not receive any specific grant from any funding agency in the public, commercial, or not-for-profit sector.

\section{Conflict of Interest}

The authors have no conflict of interest.

\section{References}

Abo, K., Sumino, K., Nishio, H., Hozumi, T., Ishida, Y., Fujieda, K., Tajima, T. \& Kazumi, T. (1999) 21-Hydroxylase deficiency presenting as massive bilateral adrenal masses in the seventh decade of life. Endocr. J., 46, 817-823.

Bachelot, A., Chakthoura, Z., Rouxel, A., Dulon, J. \& Touraine, P. (2008) Classical forms of congenital adrenal hyperplasia due to 21-hydroxylase deficiency in adults. Horm. Res., 69, 203-211.

Bauman, A. \& Bauman, C.G. (1982) Virilizing adrenocortical carcinoma. Development in a patient with salt-losing congenital adrenal hyperplasia. JAMA, 248, 3140-3141.

Carroll, M.C., Campbell, R.D. \& Porter, R.R. (1985) Mapping of steroid 21-hydroxylase genes adjacent to complement component $\mathrm{C} 4$ genes in HLA, the major histocompatibility complex in man. Proc. Natl. Acad. Sci. USA, 82, 521-525.

Dufort, I., Rheault, P., Huang, X.F., Soucy, P. \& Luu-The, V. (1999) Characteristics of a highly labile human type 517 betahydroxysteroid dehydrogenase. Endocrinology, 140, 568-574.

Hamwi, G.J., Serbin, R.A. \& Kruger, F.A. (1957) Does adrenocortical hyperplasia result in adrenocortical carcinoma. N. Engl. J. Med., 257, 1153-1157.

Higashi, Y., Tanae, A., Inoue, H., Hiromasa, T. \& Fujii-Kuriyama, Y. (1988) Aberrant splicing and missense mutations cause steroid 21-hydroxylase [P-450(C21)] deficiency in humans: possible gene conversion products. Proc. Natl. Acad. Sci. USA, 85, 7486-7490.

Homma, K., Hasegawa, T., Masumoto, M., Takeshita, E., Watanabe, K., Chiba, H., Kurosawa, T., Takahashi, T. \& Matsuo, N. (2003) Reference values for urinary steroids in Japanese newborn infants: gas chromatography/mass spectrometry in selected ion monitoring. Endocr. J., 50, 783-792.

Homma, K., Hasegawa, T., Takeshita, E., Watanabe, K., Anzo, M., Toyoura, T., Jinno, K., Ohashi, T., Hamajima, T., Takahashi, Y., Takahashi, T. \& Matsuo, N. (2004) Elevated urine pregnanetriolone definitively establishes the diagnosis of classical 21-hydroxylase deficiency in term and preterm neonates. $J$. Clin. Endocrinol. Metab., 89, 6087-6091.

Iino, K., Sasano, H., Yabuki, N., Oki, Y., Kikuchi, A., Yoshimi, T. \& Nagura, H. (1997) DNA topoisomerase II alpha and Ki-67 in human adrenocortical neoplasms: a possible marker of differentiation between adenomas and carcinomas. Mod. Pathol., 10, 901-907.

Jaresch, S., Kornely, E., Kley, H.K. \& Schlaghecke, R. (1992) Adrenal incidentaloma and patients with homozygous or heterozygous congenital adrenal hyperplasia. J. Clin. Endocrinol. Metab., 74, 685-689.

Jaursch-Hancke, C., Allolio, B., Metzler, U., Bidlingmaier, F. \& Winkelmann, W. (1988) Adrenocortical carcinoma in a patient with untreated congenital adrenal hyperplasia (CAH). Acta Endocrinologica (Copenh), 117, S146-S147.

Koyama, S., Toyoura, T., Saisho, S., Shimozawa, K. \& Yata, J. (2002) Genetic analysis of Japanese patients with 21-hydroxylase deficiency: identification of a patient with a new mutation of a homozygous deletion of adenine at codon 246 and patients without demonstrable mutations within the structural gene for CYP21. J. Clin. Endocrinol. Metab., 87, 2668-2673.

Koyama, Y., Homma, K., Fukami, M., Miwa, M., Ikeda, K., Ogata, T., Hasegawa, T. \& Murata, M. (2012) Two-step biochemical differential diagnosis of classic 21-hydroxylase deficiency and cytochrome P450 oxidoreductase deficiency in Japanese infants by GC-MS measurement of urinary pregnanetriolone/ tetrahydroxycortisone ratio and $11 \beta$-hydroxyandrosterone. Clin. Chem., 58, 741-747.

Krone, N., Braun, A., Roscher, A.A., Knorr, D. \& Schwarz, H.P. (2000) Predicting phenotype in steroid 21-hydroxylase deficiency? Comprehensive genotyping in 155 unrelated, well 
defined patients from southern Germany. J. Clin. Endocrinol. Metab., 85, 1059-1065

Lee, P.A. \& Houk, C.P. (2010) Review of outcome information in 46,XX patients with congenital adrenal hyperplasia assigned/ reared male: what does it say about gender assignment? Int. J. Pediatr. Endocrinol., 2010, 982025.

Lorence, M.C., Murry, B.A., Trant, J.M. \& Mason, J.I. (1990) Human 3 beta-hydroxysteroid dehydrogenase/delta 5-4isomerase from placenta: expression in nonsteroidogenic cells of a protein that catalyzes the dehydrogenation/isomerization of C21 and C19 steroids. Endocrinology, 126, 2493-2498.

Merke, D.P. \& Bornstein, S.R. (2005) Congenital adrenal hyperplasia. Lancet, 365, 2125-2136.

Nagasaka, S., Kubota, K., Motegi, T., Hayashi, E., Ohta, M., Takahashi, K., Takahashi, T., Iwasaki, Y., Koike, M. \& Nishikawa, T. (1996) A case of silent 21-hydroxylase deficiency with persistent adrenal insufficiency after removal of an adrenal incidentaloma. Clin. Endocrinol. (Oxf.), 44, 111-116.

Nakamura, Y., Hornsby, P.J., Casson, P., Morimoto, R., Satoh, F., Xing, Y., Kennedy, M.R., Sasano, H. \& Rainey, W.E. (2009) Type 5 17beta-hydroxysteroid dehydrogenase (AKR1C3) contributes to testosterone production in the adrenal reticularis. J. Clin. Endocrinol. Metab., 94, 2192-2198.

Nakazumi, H., Sasano, H., Iino, K., Ohashi, Y. \& Orikasa, S. (1998) Expression of cell cycle inhibitor p27 and Ki-67 in human adrenocortical neoplasms. Mod. Pathol., 11, 11651170.

Nimkarn, S., Lin-Su, K. \& New, M.I. (2011) Steroid 21 hydroxylase deficiency congenital adrenal hyperplasia. Pediatr. Clin. North Am., 58, 1281-1300, xii.

Sasano, H., Miyazaki, S., Sawai, T., Sasano, N., Nagura, H., Funahashi, H., Aiba, M. \& Demura, H. (1992) Primary pigmented nodular adrenocortical disease (PPNAD): immunohistochemical and in situ hybridization analysis of steroidogenic enzymes in eight cases. Mod. Pathol., 5, 23-29.

Shinagawa, T., Horikawa, R., Isojima, T., Naiki, Y., Tanaka, T. \& Katsumata, N. (2007) Nonclassic steroid 21-hydroxylase defi- ciency due to a homozygous V281L mutation in CYP21A2 detected by the neonatal mass-screening program in Japan. Endocr. J., 54, 1021-1025.

Stikkelbroeck, N.M., Hoefsloot, L.H., de Wijs, I.J., Otten, B.J., Hermus, A.R. \& Sistermans, E.A. (2003) CYP21 gene mutation analysis in 198 patients with 21-hydroxylase deficiency in The Netherlands: six novel mutations and a specific cluster of four mutations. J. Clin. Endocrinol. Metab., 88, 3852-3859.

Usui, T., Nishisho, K., Kaji, M., Ikuno, N., Yorifuji, T., Yasuda, T., Kuzuya, H. \& Shimatsu, A. (2004) Three novel mutations in Japanese patients with 21-hydroxylase deficiency. Horm. Res., 61, 126-132.

Wedell, A., Thilen, A., Ritzen, E.M., Stengler, B. \& Luthman, H. (1994) Mutational spectrum of the steroid 21-hydroxylase gene in Sweden: implications for genetic diagnosis and association with disease manifestation. J. Clin. Endocrinol. Metab., 78, 1145-1152.

Weiss, L.M. (1984) Comparative histologic study of 43 metastasizing and nonmetastasizing adrenocortical tumors. Am. J. Surg. Pathol., 8, 163-169.

White, P.C., Grossberger, D., Onufer, B.J., Chaplin, D.D., New, M.I., Dupont, B. \& Strominger, J.L. (1985) Two genes encoding steroid 21-hydroxylase are located near the genes encoding the fourth component of complement in man. Proc. Natl. Acad. Sci. USA, 82, 1089-1093.

White, P.C., New, M.I. \& Dupont, B. (1984) Cloning and expression of cDNA encoding a bovine adrenal cytochrome P-450 specific for steroid 21-hydroxylation. Proc. Natl. Acad. Sci. USA, 81, 1986-1990.

Wilson, R.C., Mercado, A.B., Cheng, K.C. \& New, M.I. (1995) Steroid 21-hydroxylase deficiency: genotype may not predict phenotype. J. Clin. Endocrinol. Metab., 80, 2322-2329.

Zhang, H.J., Yang, J., Zhang, M.N., Zhang, W., Liu, J.M., Wang, W.Q., Ning, G. \& Li, X.Y. (2009) Variations in the promoter of CYP21A2 gene identified in a Chinese patient with simple virilizing form of 21-hydroxylase deficiency. Clin. Endocrinol. (Oxf.), 70, 201-207. 